\title{
The efficiency of microbial protein synthesis in the rumen and the degradability of feed nitrogen between the mouth and abomasum in steers given different diets
}

\author{
By A. B. MCALLAN AND R. H. SMITH \\ National Institute for Research in Dairying, Shinfield, Reading RG2 9AT, Berkshire
}

(Received 29 April 1983 - Accepted 25 July 1983)

\begin{abstract}
1. Protozoa-free steers with simple rumen and abomasal cannulas were given basal diets consisting of a concentrate mixture of flaked maize and tapioca with barley straw (BS) or alkali-treated barley straw (BSA). Other diets were supplemented with urea (BSU and BSAU respectively) or with fish meal replacing the tapioca (BSF and BSAF respectively). The diets were isoenergetic and calculated to provide sufficient metabolizable energy (ME) to support a growth rate of $0.5 \mathrm{~kg} / \mathrm{d}$. Rumen-degradable nitrogen (RDN):ME values (g/MJ) were estimated to be $0.50,1.20$ and 0.80 for the basal diet, urea- and fish-meal-supplemented diets respectively. RNA and $\alpha, \epsilon$-diaminopimelic acid (DAP) were used as microbial markers. ${ }^{103}$ Ruthenium and polyethylene glycol (PEG) were given as flow markers and flows $(\mathrm{g} / 24 \mathrm{~h})$ at the abomasum of organic matter (OM) and nitrogenous constituents were calculated.

2. Samples of mixed bacteria separated from rumen digesta from animals receiving $\mathrm{N}$-supplemented diets contained significantly more $N$ than those from animals receiving basal diets (approximately 74 and $62 \mathrm{mg} / \mathrm{g} \mathrm{dry}$ matter (DM) respectively) but there were no other significant differences in total- $\mathrm{N}$ contents between treatments. RNA-N : total-N values were similar for all diets (approximately $0 \cdot 13$ ). DAP-N : total-N values were significantly lower in bacteria from animals receiving alkali-treated (AT) rather than untreated (UT) straw (approximately 0.008 and 0.011 respectively).

3. The proportion of OM intake digested in the rumen (ADOM) was significantly higher for animals receiving AT straw rather than UT straw (approximately 0.54 and 0.43 respectively). $\mathrm{N}$ supplementation had no effect on OM digestibility.

4. When basal rather than N-supplemented diets or AT-straw- rather than UT-straw-containing diets were given, there were significantly lower flows of ammonia-N, non-ammonia-N (NAN) and microbial-N (based on RNA flow, MN(RNA)) at the abomasum. Mean daily MN(RNA) flows (g) were 21, 30, 31, 16, 27 and 28 for diets BS, BSU, BSF, BSA, BSAU and BSAF respectively. These correspond to estimated efficiencies of microbial protein synthesis, expressed as $\mathrm{g}$ MN(RNA)/ $\mathrm{kg}$ truly-digested $\mathrm{OM}$, at 14,22, 22,12, 18 and 19 respectively. Values were significantly lower for basal as compared with corresponding $\mathrm{N}$-supplemented diets and for AT-straw diets as compared with corresponding UT-straw diets.

5. Estimated mean proportions of total feed-N intake degraded in the rumen, based on MN(RNA) as microbial marker, of diets BS, BSU and BSF were $0.60,0.74$ and 0.47 respectively; corresponding values for diets BSA, BSAU and BSAF were $0.72,0.73$ and 0.36 respectively. Making certain assumptions, the mean proportions of fish-meal-N digested in the rumen were calculated to be 0.23 and 0.14 respectively for UT-and AT-straw diets. The values were not significantly different. Values for microbial flows based on DAP as marker were significantly lower, by about $25 \%$, than those based on RNA.
\end{abstract}

Investigations with steers (McAllan \& Smith, 1983a), have demonstrated that the increased organic matter (OM) digestibility of straw resulting from sodium hydroxide treatment is largely a result of increased rumen digestibilities of hemicellulose neutral sugars and cellulose-glucose, and have supported other studies (Elliott \& Armstrong, 1982) in showing that to achieve maximum digestion of alkali-treated straws, supplementary dietary nitrogen is required.

Such effects are likely to be of importance in determining the value of alkali-treated roughage as a feed but other factors may also play a part. Thus, for example, an increased intake of sodium may in itself influence microbial activity by affecting rates of flow of digesta from the rumen (Hogan \& Weston, 1971; Berger et al. 1980), microbial ureolytic or proteolytic activity (Jones et al. 1964; Ololade \& Mowat, 1975) or rates of fermentation (Van Eenaeme et al. 1979). 
Table 1. Amounts of main dietary components (dry matter $(D M ; \mathrm{kg} / \mathrm{d})$, nitrogen $(\mathrm{g} / \mathrm{d})$ and metabolizable energy $(M E ; M J / d))$ given to steers weighing $110-129 \mathrm{~kg}^{*}$

\begin{tabular}{|c|c|c|c|c|c|c|}
\hline \multirow[b]{2}{*}{ Component } & \multicolumn{6}{|c|}{ Diet } \\
\hline & BS & BSU & BSF & BSA & BSAU & BSAF \\
\hline Flaked maize & $1 \cdot 30$ & $1 \cdot 30$ & $1 \cdot 30$ & $1 \cdot 30$ & $1 \cdot 30$ & $1 \cdot 30$ \\
\hline Untreated barley straw & $1 \cdot 30$ & $1 \cdot 30$ & $1 \cdot 30$ & - & - & - \\
\hline Alkali-treated barley straw & - & - & - & $1 \cdot 30$ & $1 \cdot 30$ & $1 \cdot 30$ \\
\hline Tapioca & 0.26 & $0 \cdot 24$ & - & 0.26 & 0.24 & - \\
\hline Fish meal & - & - & 0.26 & - & - & 0.26 \\
\hline Urea & - & 0.048 & - & - & 0.048 & - \\
\hline $\mathrm{N}$ & $25 \cdot 2$ & $46 \cdot 6$ & $57 \cdot 1$ & $25 \cdot 5$ & 47.0 & 57.5 \\
\hline Estimated RDN† & $16 \cdot 4$ & 36.7 & $23 \cdot 8$ & 16.4 & 36.8 & 23.9 \\
\hline ME & 31.5 & $31 \cdot 2$ & $31 \cdot 0$ & 31.5 & $31 \cdot 2$ & $31 \cdot 0$ \\
\hline
\end{tabular}

RDN, rumen-degradable-N.

* These amounts were increased by $8 \%$ for each succeeding $20 \mathrm{~kg}$ weight range.

$\dagger$ Using rumen degradabilities derived in the present experiment.

$\$$ Calculated from energy values for individual components (Ministry of Agriculture, Fisheries and Food, 1975).

The present experiments were designed to study the effects of giving diets containing $\mathrm{NaOH}$-treated straw on the efficiency of microbial protein synthesis and the degradability of supplementary $\mathrm{N}$ sources in the rumen of steers.

\section{METHODS \\ Animals, diets and collection of digesta}

Details of diets and animal experimentation have been described elsewhere (McAllan \& Smith, 1983b). In summary, six Friesian steers, virtually protozoa-free, each fitted with simple rumen and abomasal cannulas were used. The steers had mean (with SE) body-weights $(\mathrm{kg})$ of $116(17)$ and $157(21)$ and mean (with SE) ages (weeks) of $22.9(4.0)$ and $39.6(4.0)$ at the beginning and end of the experiment respectively. Six isoenergetic diets were given in a $6 \times 6$ Latin-square design (Table 1). Three contained untreated (UT) barley straw and three, alkali-treated (AT) barley straw. Basal diets consisted of flaked maize and tapioca with either chopped UT straw (BS) or AT straw (BSA). Other diets were supplemented with urea (BSU and BSAU respectively) or had tapioca replaced by fish meal (BSF and BSAF respectively). Diets were given in two equal portions at 09.00 and 17.00 hours.

Each experimental period lasted for $20 \mathrm{~d}$ at the end of which time diets were changed. Polyethylene glycol (molecular weight 4000 ; PEG) and ${ }^{103}$ ruthenium (as a soluble Ruphenanthroline complex) were introduced directly into the rumen at each feed from day 9 onwards. On day 18, samples (approximately $150 \mathrm{~g}$ ) of abomasal digesta were taken immediately before the morning feed and then at 3-hourly intervals over the next $21 \mathrm{~h}$. These samples were homogenized and subsamples $(100 \mathrm{~g})$ were combined and stored for subsequent analysis. On day 19, samples of rumen digesta (approximately $250 \mathrm{~g}$ ) were taken at $4,8,12,16$ and $24 \mathrm{~h}$ after the morning feed and combined. Mixed bacteria were separated as described by Smith \& McAllan (1974).

\section{Analytical}

Total-N and ammonia-N were estimated by the methods described by Smith \& McAllan (1970). $\alpha, \epsilon$-Diaminopimelic acid (DAP) was determined according to the procedure of Smith et al. (1978). RNA was determined in fresh samples of abomasal digesta and of bulked 


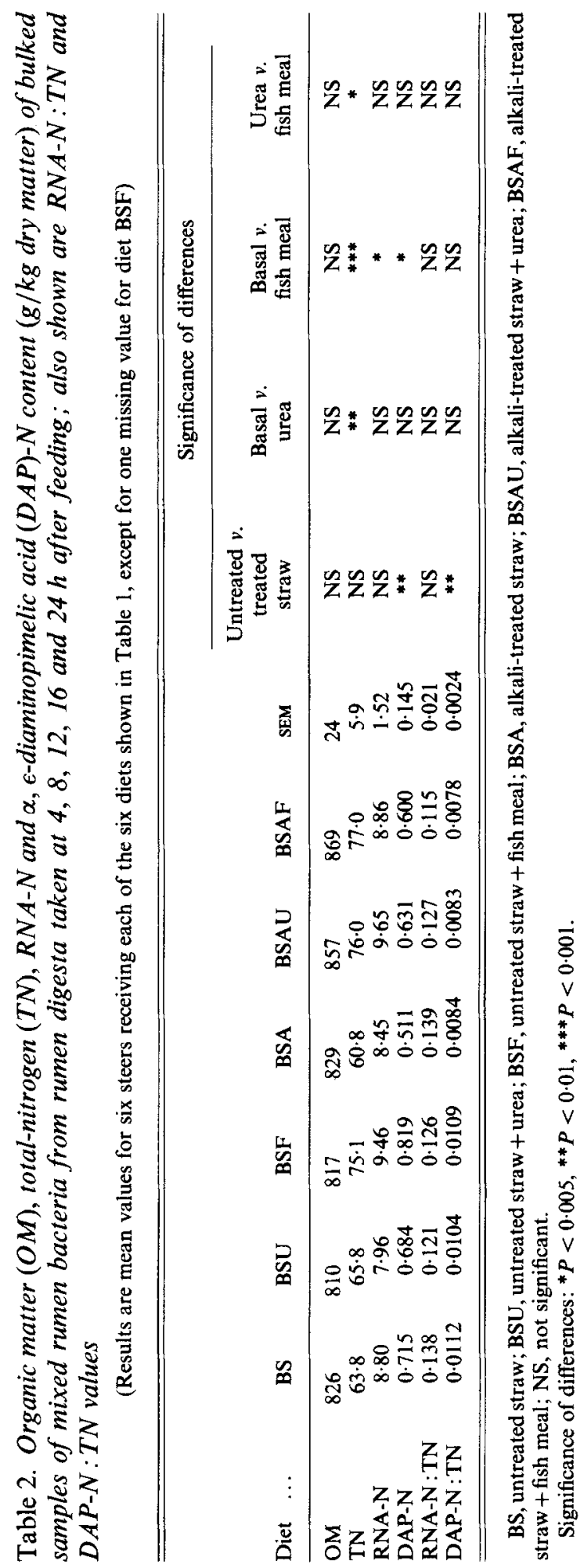


mixed rumen bacteria by the method of McAllan \& Smith (1969). RNA and DAP were used as indices of microbial-N in abomasal digesta as described by McAllan \& Smith $(1983 a)$. Other analyses and the method of calculating flows of digesta components entering the abomasum were described by McAllan \& Smith (1983b).

Analysis of variance was carried out according to Cochran \& Cox (1962).

\section{RESULTS}

\section{Bacterial composition}

Values for samples of mixed rumen bacteria from animals receiving the different diets are shown in Table 2. OM contents were similar for all diets. Giving AT straw rather than UT straw had no apparent effect on the total- $\mathrm{N}$ content of bacteria but total- $\mathrm{N}$ was significantly greater for animals receiving urea- or fish-meal-supplemented diets rather than basal diets, with fish meal producing a significantly greater effect than urea. RNA-N contents of mixed bacteria were also greater for the $\mathrm{N}$-supplemented diets (significantly so for fish meal) and RNA-N : total-N values were similar on all diets. DAP-N content of mixed bacteria was significantly lower in animals receiving AT straw rather than UT straw and DAP-N : total-N values were significantly lower in bacteria from animals receiving the former diets.

\section{Flow-rates at the abomasum}

Total daily flows of various nitrogenous constituents in digesta passing the abomasum are presented in Table 3 . Ammonia- $\mathrm{N}$ flows were generally low and were significantly less when AT straw replaced UT straw in the diets. Supplementation of the basal diets with $N$ significantly increased the flows of ammonia- $\mathrm{N}$ at the abomasum. Non-ammonia-N (NAN) flows for the basal diets were significantly less when AT straw rather than UT straw was given but this difference was not seen for the supplemented diets. Supplementation with either $\mathrm{N}$ source, however, significantly increased abomasal flows of NAN with fish meal producing significantly greater flows than urea (Table 3 ).

Flows of DAP-N, RNA-N and microbial-N calculated using RNA as a marker, were significantly lower for diets containing AT straw compared with UT straw (Table 3 ), and supplementation with urea and fish meal both significantly increased these flows. Microbial-N flows calculated using DAP-N as a microbial marker, showed the same trends as those based on RNA-N (Table 3) but were on average about $74 \%$ of the RNA-based values. This difference was significant. Microbial-N (based on RNA-N) contributed on average approximately $73 \%$ of the NAN at the abomasum in animals receiving basal and ureasupplemented diets and approximately $50 \%$ in animals receiving fish-meal-supplemented diets. The latter value was significantly lower than the former.

Estimates of total feed-N degradability for the basal diets were significantly greater when AT straw rather than UT straw was used, but no significant differences were found for the $\mathrm{N}$-supplemented diets (Table 3). Estimated degradabilities of the supplementary fish-meal-N alone are also given in Table 3 . Values were very low $(\leqslant 27 \%)$ for both types of straw and irrespective of the microbial marker used.

\section{DISCUSSION}

The techniques available for estimating microbial-N flow at the abomasum or duodenum all have deficiencies and uncertainties and these have frequently been discussed (e.g. Smith et al. 1978; Siddons et al. 1982). In the present studies the two methods used to make this estimate (based respectively on RNA and DAP as markers) gave different absolute results but similar relative patterns when different dietary treatments were compared. No absolute yardstick exists to show reliably which method is the more accurate but the methods depend 
Microbial protein synthesis and feed- $N$ degradability

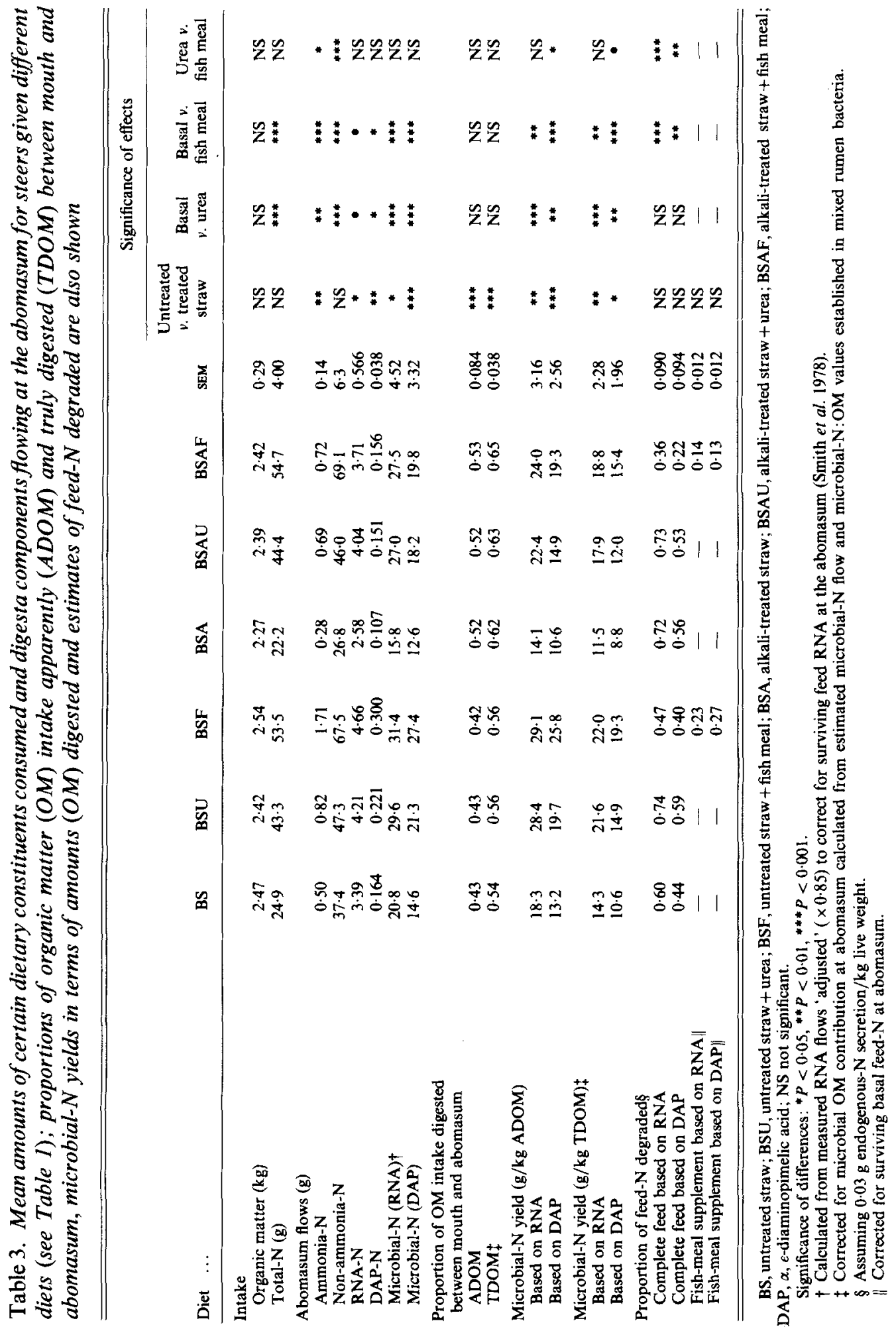


on the assumption that the ratio, $\mathrm{N}$ :marker in a sample of bacteria separated from rumen fluid represents the composition of the microbial fraction flowing out of the reticulum to the omasum. Present findings supported earlier observations (Smith et al. 1975) and other recent findings (Merry \& McAllan, 1983) in indicating that the DAP contents of different samples of mixed rumen bacteria vary, for a number of causes, to a greater extent than RNA contents and for this reason, in subsequent references to microbial-N, calculations based on RNA content were preferred.

Values for the efficiency of microbial-N synthesis ( $\mathrm{g} \mathrm{N} / \mathrm{kg}$ apparently digested $\mathrm{OM}$ ) obtained for the N-supplemented UT-straw diets (28-29) were close to the mean value for a variety of diets (30) reported by the Agricultural Research Council (1980),

Calculated values for the proportion of dietary $\mathbf{N}$ degraded between mouth and duodenum were in general agreement, for the basal and urea-supplemented diets, with those found in earlier experiments. The dietary fish meal was found to be of unexpectedly low degradability and this meant that estimated rumen-degradable-N (RDN) values for diets BSF and BSAF were lower than anticipated. Estimates of RDN:ME (g/MJ) were approximately $0.5,1.2$ and 0.8 for basal, urea and fish-meal diets respectively. Only the urea-containing diets were close to the minimum value $(1.25)$ recommended by the Agricultural Research Council (1980).

The findings of relatively-low $\mathrm{N}$ contents of mixed bacteria samples separated from rumen contents and low efficiencies of microbial $\mathrm{N}$ synthesis for the basal diets compared with the N-supplemented diets were in accord with earlier observations and were presumably the result of depressed growth rate (McAllan \& Smith, 1977; Smith et al. 1978; Elliott \& Armstrong, 1982; McAllan \& Smith, 1983a). The significantly lower microbial synthetic efficiency observed when AT straw rather than UT straw was given as the dietary fibre component is less easy to explain.

Differences between UT and AT straw could have been associated with a number of factors. For example, high $\mathrm{Na}$ intakes have been reported to result in inhibition of ureolytic and proteolytic activity (Jones et al. 1964; Ololade \& Mowat, 1975), reduced growth of some species of bacteria (Stewart et al. 1979) and depressed fermentation (Durand \& Kawashima, 1980). It is apparent that a variety of effects having opposing consequences for microbial synthetic efficiency may follow from the use of AT straw, and it appears that inhibitory factors were dominant in the present experiments and led to the depression in microbial synthetic efficiency observed. This depression as a result of feeding AT straw is contrary to that reported by Redman et al. (1980) who found a non-significant increase in the efficiency of microbial synthesis (measured by an unspecified technique using DAP) in bulls when AT straw replaced UT straw. It is, however, supported by the in vitro findings of Van Eenaeme et al. (1979) who found lower total cell growth and slower fermentation in digesta from animals receiving AT straw compared with UT straw.

Another consequence of alkali treatment is a very great increase in the number of adhesion sites available to adhering cellulolytic bacteria (Latham et al. 1979). These include many gram positive cocci (Latham, 1980) likely to lack DAP (Work \& Dewey, 1953) and the significantly lower DAP: $N$ value found in mixed bacteria in the present experiments for animals receiving AT straw rather than UT straw probably indicates a marked shift in the composition of the microbial population of this kind. This emphasizes the fact that a change in conditions is likely to affect one compartment of the heterogeneous microbial population differently from another. This conclusion is compatible with the finding previously reported (McAllan \& Smith, 1983b) that treating straw with alkali or replacing urea by fish meal as the protein supplement may lead to increased fibre digestion in the reticulo-rumen even though microbial growth efficiency, measured in terms of microbial- $\mathrm{N}$ flow into the abomasum, is unchanged or even depressed. 
The authors thank Dr H. L. Buttle for the insertion of cannulas, Mrs C. Chard and staff for the care and maintenance of the animals and Miss P. E. Lewis and Mr E. S. Griffith for skilled technical assistance.

\section{REFERENCES}

Agricultural Research Council (1980). The Nutrient Requirements of Ruminant Livestock. Slough: Commonwealth Agricultural Bureaux.

Berger, L. L., Klopfenstein, T. J. \& Britton, R. A. (1980). Journal of Animal Science 50, 745-749.

Cochran, W. G. \& Cox, G. M. (1962). Experimental Designs, 2nd ed., p. 50. New York: J. Wiley \& Sons Inc.

Durand, M. \& Kawashima, R. (1980). In Digestive Physiology and Metabolism in Ruminants, p. 375 [Y. Ruckebusch and P. Thivend, editors]. Lancaster: MTP Press Ltd.

Elliott, R. \& Armstrong, D. G. (1982). Journal of Agricultural Science, Cambridge 99, 51-60.

Hogan, J. P. \& Weston, R. H. (1971). Australian Journal of Agricultural Research 22, 951-962.

Jones, G. A., MacLeod, R. A. \& Blackwood, A. C. (1964). Canadian Journal of Microbiology 10, 379-387.

Latham, M. J. (1980). In Microbial Adhesion to Surfaces, p. 339 [R. C. W. Berkeley, J. M. Lynch, J. Melling, P. R. Rutter and B. Vincent, editors]. Chichester: Ellis Horwood.

Latham, M. J., Hobbs, D. G. \& Harris, P. J. (1979). Annales de Recherche Veterinaires 10, 244-245.

McAllan, A. B. \& Smith, R. H. (1969). British Journal of Nutrition 23, 671-681.

McAllan, A. B. \& Smith, R. H. (1977). British Journal of Nutrition 37, 55-65.

McAllan, A. B. \& Smith, R. H. (1983a). British Journal of Nutrition 49, 119-127.

McAllan, A. B. \& Smith, R. H. (1983 b). British Journal of Nutrition 50, 445-454.

Merry, R. J. \& McAllan, A. B. (1983). Proceedings of the Nutrition Society 42, 49A.

Ministry of Agriculture, Fisheries and Food (1975). Technical Bulletin no. 33. London: H.M. Stationery Office.

Ololade, B. G. \& Mowat, D. N. (1975). Journal of Animal Science 40, 351-357.

Redman, R. G., Kellaway, R. C. \& Leibholz, J. (1980). Proceedings of the Australian Society of Animal Production 13,482 .

Siddons, R. C., Beever, D. E. \& Nolan, J. V. (1982). British Journal of Nutrition 48, 377-389.

Smith, R. H. \& McAllan, A. B. (1970). British Journal of Nutrition 24, 545-556.

Smith, R. H. \& McAllan, A. B. (1974). British Journal of Nutrition 31, 27-34.

Smith, R. H., McAllan, A. B., Hewitt, D. \& Lewis, P. E. (1978). Journal of Agricultural Science, Cambridge 90 , 557-568.

Smith, R. H., Salter, D. N., Sutton, J. D. \& McAllan, A. B. (1975). Tracer Studies on Non-protein Nitrogen for Ruminants, vol. 2, pp. 81-93. Vienna: International Atomic Energy Authority.

Stewart, C. S., Dinsdale, D., Cheng, K.-J. \& Paniagua, C. (1979). In Straw Decay and its Effect on Disposal and Utilisation, pp. 123-130 [E. G. Grossbard, editor]. Chichester: J. Wiley.

Van Eenaeme, C., Lambot, O., Bienfait, J. M., Nicks, B. \& Van Nevel, C. J. (1979). Annales de Recherche Veterinaires 10, 323-325.

Work, E. \& Dewey, D. L. (1953). Journal of General Microbiology 9, 394-399. 